\title{
Sociocultural factors in Brazilian neuropsycholinguistic studies
}

\author{
Maria Alice de Mattos Pimenta Parente, ${ }^{1}$ Maria Teresa Carthery-Goulart, ${ }^{1}$ Nicolle Zimmermann, ${ }^{2}$ \\ Rochele Paz Fonseca ${ }^{2}$ \\ 1 - Universidade Federal do ABC, Santo André, SP, Brazil \\ 2 - Pontifícia Universidade Católica do Rio Grande do Sul, Porto Alegre, RS, Brazil
}

\begin{abstract}
The history of Brazilian neuropsychology is traced at different neuropsycholinguistic stages with a focus on the importance of sociocultural factors. We first focus on language disorders, the sequelae of injuries in the left hemisphere, and neuropsychology restricted to the medical field in Europe, the United States, and Brazil. In the middle of the last century, attention to the interdisciplinary importance of studies on the right hemisphere began. Studies consequently emerged on the individual variability of brain function with both biological and cultural origins. Based on this approach, Brazilian studies on aphasic children and illiterate aphasic persons were disseminated internationally. In the 1970s, cognitive neuropsychology began in England, highlighting dysfunctions in reading and writing processes. The characteristics of writing systems within each language became relevant for the manifestations of acquired dyslexia. Brazilian studies showed deficits in Portuguese and Japanese writing caused by brain lesions. During this scientific journey, scientific societies and postgraduate programs in Brazil were created to facilitate exchanges and communication among young researchers. By the end of the last century and in the early 2000 s, the growth of the neuropsychology of aging raised awareness of the complexity of sociocultural factors, not only on language research but also according to the level of education, frequency of reading and writing habits, school type, and interactions among these factors and biological factors, especially between the level of education and age. From this historical standpoint, we outline future directions and perspectives in the field of Brazilian neuropsychology.
\end{abstract}

Keywords: neuropsycholinguistics; neuropsychological assessment; neuropsychological history; education; literacy; aphasia

Received 26 November 2012; received in revised form 13 December 2012; accepted 14 December 2012. Available online 28 December 2012.

\section{Introduction}

The goal of this review is to present a historical description of Brazilian neuropsychology, indicating how and when studies on social factors in the organization of the human brain emerged. To conceptualize the paths of Brazilian neuropsychology, we present a parallel comparison of the paths that were followed worldwide. Brazilian studies accompanied scientific advances in Europe and North America and also interact with the neuropsychology studies of Latin America. Four critical changes in Brazilian neuropsychology are examined:

Maria Alice de Mattos Pimenta Parente and Maria Teresa Carthery-Goulart, Universidade Federal do ABC - UFABC, Santo André, SP, Brazil. Nicolle Zimmermann and Rochele da Fonseca, Pontifícia Universidade Católica do Rio Grande do Sul - PUCRS, Porto Alegre, RS, Brazil. Correspondence regarding this article should be directed to: Rochele Paz Fonseca, Av. Ipiranga, 6681 - Partenon - Porto Alegre, RS, Brazil, Pontifícia Universidade Católica do Rio Grande do Sul PUCRS, Phone: 5551 3320-3500 ramal 7742. E-mail: rochele. fonseca@gmail.com
1. From the scientific field of neurology, neuropsychology becomes an interdisciplinary field with transdisciplinary approaches.

2. Based on a predominant interest in cognitive functions associated with the left hemisphere and aphasias, at the end of the 1960s there was an increased interest in the functions of the right hemisphere and subcortical areas. Since the beginning of the brain decade in the 1990s, interest in neural correlates extended to the cerebellum.

3. With the advent of cognitive neuropsychology in the middle of the $1970 \mathrm{~s}$, the initial focus on the relationship between language and neural substrates began to include relationships between linguistic components and other cognitive components such as memory, attention, and emotion.

4. Based on a theory of the universal organization of the adult brain, genetic and social factors that determine or alter the organization of the adult brain constitute an important area of neuropsychology.

Research at the beginning of the history of neuropsychology did not ignore the aspects mentioned above. Neuropsychology initially focused on studies of language, but a few years after the studies by Broca (1863, 
1866), neuropsychological studies began to investigate organic substrates and other cognitive functions such as vision and mathematic calculations. Regarding interindividual variations in brain organization associated with cognitive function, Broca suggested that left-handed individuals might have cerebral representations different from right-handed individuals.

The present article describes the following development of Brazilian neuropsychology: (1) the initial predominance of a medical approach, (2) the history of a multidisciplinary approach, (3) studies on the right hemisphere, and (4) the importance of social factors for cerebral organization, which is the focus of the present review.

\section{The Beginning of Brazilian Neuropsychology}

The first Brazilian studies on brain function came out only 20 years after the pioneering studies by Broca, which is not a very long period of time considering the communication limitations that existed at that time. At Universidade Federal do Rio de Janeiro (UFRJ), likely because of the influence of Prof. Antônio Austregésilo who founded the first school of neurology in Brazil, two theses on aphasia were published at the end of the 19th century (Caldas, 1891; Goulart, 1891). Three others were published during the first few decades of the 20th century (Campos, 1921; Pinto, 1910; Souza, 1908). At that time, another thesis was also published at Universidade da Bahia, also on aphasia (Sampaio, 1912). In 1940, Prof. Austregésilo published an article in France about aphasia and the lateral lobe (Austregésilo, 1940). In São Paulo, studies on the so-called higher cortical function appeared later in 1950 with a pioneering thesis by Prof. Antônio Branco Lefèvre in the Faculdade de Medicina (Lefèvre, 1950).

These pioneering works retained the characteristics of neuropsychology as a medical area, highlighting the importance of language disorders and the left hemisphere. In the middle of the last century, the term "superior cortical function" was commonly used to define a set of cognitive functions and their brain correlates. The term neuropsychology only began to be disseminated in Brazil at the end of the last century. Theses in this area came out between 1980 and 1990 at Universidade de São Paulo and UFRJ (Amaral, 1980; Parente, 1990).

\section{History of Interdisciplinary Neuropsychology}

The interdisciplinary practice of neuropsychology began by other professionals between World Wars I and II, mainly consisting of speech therapy for individuals who sustained brain injuries during war time. In Europe, the beginning of the interdisciplinary practice of neuropsychology was marked by the publication of the book Le syndrome de désintégration phonétique dans l'aphasie in 1939, whose authors were the neurologist Théophile Alajouanine, linguist Marguerite Durand, and psychologist André Ombredane (Alajouanine, Ombredane, \& Durand, 1939).

Interestingly, after fleeing World War II, the psychologist Ombredane was a professor of experimental psychology at Universidade do Rio de Janeiro between 1939 and 1945. At that time, he unfortunately did not provide contributions to neuropsychology. The focus of his publications was on experimental psychology and neuropsychiatry (Ombredane, 1943-1944a, b, c). Although his practice focused mainly on experimental psychology, one of Ombredane's students was the young physicist Prof. Antônio Branco Lefèvre, who is considered a pioneering researcher of aphasic children in Brazil and who favored multidisciplinary work.

At the same time, interdisciplinary works also came out in the Soviet Union. During the Cold War, Soviet research was developed independently from Europe and North America. Alexander Luria, an important theorist on functional systems, presented extensive and comprehensive works by publishing his book Higher cortical functions in man (Luria, 1966) in which he demonstrated transdisciplinary knowledge. In his teachings, Luria complemented his medical and psychology training with deep linguistic knowledge. This transdisciplinary approach, in which one researcher or practitioner in neuropsychology has expertise in different areas, was actually a quite modern concept, bolstered and strengthened by the creation of postgraduate and specialized courses in neuropsychology, neuroscience, and cognition.

Importantly, Luria referred to his scientific field as neuropsychology, whereas Critchley still used the term aphasiology at the same time in England (Critchley, 1957). Critchley's definition of this term was that it covered all cognitive functions, with a majority of studies on language disorders. Critchley highlighted studies on the functions of the left hemisphere as a prevailing concept of cerebral dominance until the middle of the last century.

In Brazil, the interdisciplinary approach was delayed by $30-40$ years when the first interdisciplinary groups were created, composed of psychologists and speech therapists who began to develop important rehabilitation strategies for aphasic patients.

Several examples of pioneering work in the mid1970s developed in Brazil can be cited. First, Prof. Lefèvre and his wife, psychologist Beatriz Lefèvre, presented their work on aphasic children at scientific meetings and in publications (Lefèvre \& Lefèvre, 1975). Second, in 1974, an article was published in the journal of the Serviço de Neurocirugia e Neurologia of Escola Paulista de Medicina. Today it is called Faculdade de Medicina da Universidade Federal de São Paulo (UNIFESP). The study involved 100 patients with brain tumors who were examined by Luria. The authors also included the phonoaudiologist Maria Alice Parente and neurosurgeon Aloysio de Mattos Pimenta 
(Parente, 1974; Parente \& Pimenta, 1977). Third, two neurology and neurosurgery services were founded that focused on epilepsy studies, one in the Faculdade de Medicina da USP (with the work of neuropsychologist Cândida P. Camargo) and the other at PUCRS (with the work of Mirna W. Portuguez). In the phonoaudiology field, research on evaluating and rehabilitating aphasic individuals was also performed but without the strong interdisciplinary collaborations that usually occurred in hospital environments, such as the contribution of Prof. Regina Jacubovics (Jacubovics \& Cupello, 2005) in Rio de Janeiro. These works followed the studies by phonoaudiologists who were dedicated to the treatment of brain-injured individuals after World Wars I and II, such as Hildred Schuell (Schuell, Jenkins, \& JiménesPabon, 1964) and Martha Taylor Sarno (Marks, Taylor, \& Rusk, 1957; Taylor, 1958) in the United States and Blanche Ducarne de Ribancourt (Ribancourt, 1988) in France. Until then, aphasic research and studies on the dominance of the left hemisphere predominated in neuropsychology.

Brazilian neuropsychology was always closely related to advances made in Europe and North America. Some publications by Prof. Austregésilo (1940) came out in France, and Prof. Branco Léfévrè published his work on aphasic children in a book by Lenneberg (Lefèvre, 1975).

In 1980 in São Paulo, the $1^{\text {st }}$ Congresso Internacional de Afasia was organized and included South American researchers and some emerging researchers from North America and Europe such as Prof. Antônio Damásio. At that time, he began to be interested in frontal lobe dysfunction. He assisted psychologist Arthur Benton, who was then the head of the Center for Neuropsychology at the University of Iowa but was later replaced by Damásio. His wife, Ana Damásio, also began to explore new ways to study brain images, and explained the rationale of a brand new technology for this time, the computed tomography, still unknown in South America. This meeting also strengthened the relationship between Brazilian and Latin American aphasia researchers such as Carlos Mendilaharsu, the founding member of the Sociedade de Neurologia e Neurocirurgia do Uruguai and who, at that time, was the only South American member of the Aphasia Academy, and Jorge-Gonzáles Cruchagas, the founder of Sociedade Chilena de Neuropsicologia in 1970.

In 1981, a neurolinguist from Brussels, Ivan Lebrun, and the Canadian neurologist André Roch Lecours, visited UNIFESP. Dr. Lebrun subsequently published an elegant book-Tratado de Afasias (Lebrun \& Parente, 1983) - in which he discussed controversial issues such as metalinguistic activity and aphasia in bilingual children. Prof. Lecours proposed international collaborations that involved exchanges of students and researchers with funding from $\mathrm{CNPq}$ and CAPES for more than 20 years.

In the introduction to the book Tratado de Afasias, Dr. Lebrun defined neurolinguistics, a term that was soon replaced by neuropsychology, as an area of multidisciplinary knowledge but within a well-defined field that requires specific models, methods, and techniques so that it does not simply become an amalgam of knowledge. This thinking reflected changes in interdisciplinary work in which various professionals collaborate, each with their specific contribution, to transdisciplinary work. The goal in this area was to create a specific scientific field that involves knowledge gained from multiple disciplines.

By this stage in the history of neuropsychology in Brazil and worldwide, language was the neurocognitive function that was mainly studied. Among its neural correlates, classic areas of the left hemisphere continued to be the most associated with linguistic components and other cognitive components such as visual perception and praxis (Fonseca, Scherer, Oliveira, \& Parente, 2009). New aspects of functional neuroanatomical relationships and individual differences such as age, education, bilinguism, etc. enriched the theorymethodology corpus of neuropsychology.

\section{Social Factors, Organization of Language, and the Right Hemisphere: Aphasia in Illiterates}

Studies on the importance of the right hemisphere gained momentum with the work of Roger Wolcott Sperry (1913-1994) on hemispherectomized patients. The impact of his article in the journal Science (Sperry, 1961) triggered a series of studies and theories about cerebral dominance in language and the importance of the right hemisphere. In these studies, Sperry and collaborators showed that patients with a "split brain" without hemispheric connections controlled the right hand through language, whereas the left hand lacked language commands but retained visual recognition.

The organization of the two hemispheres was understood to be distributed in a linguistic hemisphere (i.e., the left hemisphere) and nonlinguistic hemisphere (i.e., the right hemisphere; Kimura, 1961). Because this dichotomy was not entirely clear, other models were postulated such as $(i)$ a hemisphere with more analytical processing (i.e., the left hemisphere) and ( $i i)$ a hemisphere with more global processing (i.e., the right hemisphere; Levy-Agresti \& Sperry, 1968). Additionally, attention models allowed studies on hemispheric functions such as dichotic listening and tachystoscopic presentation. Those experimental paradigms-dichotic listening and tachystoscopic presentation-provided a method of studying hemispheric relationships with cognitive function when imaging techniques such as functional magnetic resonance were not yet available (Kinsbourne, 1973; Parente \& Tiedemann, 1990).

The importance given to the right hemisphere and its role in the recovery of language when an injury to the left hemisphere occurs intensified studies of individual variability. The notion of a universal brain began to be deconstructed, i.e., studies obtained by normally welleducated adults in Europe and United States could be 
transposed immediately to all populations including children. Brazilian studies on the factors that influence human brain organization reached international prominence.

In some individuals, the representation of language can be reversed (i.e., it occurs in the right hemisphere) or more diffused in both hemispheres (Springer et al., 1999). This idea corroborated the suggestion of Broca (1863) in which the cerebral dominance of the left hemisphere can be diverse in left-handed individuals. If the right hemisphere has some linguistic properties, then it can help in the rehabilitation process in aphasic patients with lesions of the left hemisphere.

Brazilian studies published between 1970 and 1980 postulated that biological and social factors contribute to language processing in the right hemisphere (Lecours et al., 1988). Focusing on biological factors and neurodevelopment, studies on aphasic children by Prof. Lefèvre became internationally known with the publication of a book by Lenneberg and Lenneberg (1975). In his chapter, Prof. Lefèvre (1975) analyzed cases of acquired childhood aphasia, showing that its symptoms were consistent with the theory of a critical period for language development in which the ideal time for the acquisition of language occurs during the second year of life. Before the age of 2 years, language is diffusely represented in both hemispheres. In children, a predominance of motor aphasia was observed with a higher degree of aphasia after lesions of the right hemisphere and a better prognosis for recovery.

The theory of Lenneberg and these characteristics of aphasic children were refuted 30 years later by the work of Woods and Teuber (1978). These authors found that, until the 1930 s, $35 \%$ of 490 registered cases had aphasia after lesions of the right hemisphere. After that time, the authors observed a decrease in the number of cases of aphasia due to right brain lesions, showing that only $8 \%$ of 270 cases of right brain lesions had aphasia in the papers reviewed after 1930, indicating the occurrence of aphasia in $5 \%$ of left-handed individuals. This publication reported an incidence of aphasia in children that was similar to adults (Woods \& Teuber, 1978).

However, a decline in support for the theory of a critical period did not lessen the importance of the pioneering work of Lefèvre (1975) or expansion of neuropsychological studies to other age groups. Notably, the psychologist Beatriz Lefèvre continued her husband's work by creating, together with Prof. Lefèvre, a neuropsychological evaluation for children based on Luria and Piaget's theories. She also maintained a neuropsychology service for many years at the Hospital das Clínicas da Faculdade de Medicina da USP where many psychologists received training in this area (Lefèvre \& Lefèvre, 1983).

In 1981, Dr. André Roch Lecours came to Brazil to conduct research funded by the Guggenheim Foundation of New York as director of the Laboratório Théophile Alajouanine at the University of Montreal, Canada, together with his colleague Prof. Jacques Mehler from
École des Hautes Études in Paris who was editor of the journal Cognition. The goal of this research was to investigate whether literacy and education influence the organization of language in the left hemisphere. The effect and severity of aphasia in illiterate and literate individuals were studied. Because illiteracy in Canada and France was almost absent, the Guggenheim Foundation funded Prof. Lecours to travel to developing countries including Brazil. Neurologists, psychologists, and phonoaudiologists from Porto Alegre, Blumenau, Curitiba, Brasília, Salvador, and Recife participated and generated three important international publications.

In Brazil, $\sim 300$ participants were evaluated using a short aphasia examination battery. The participants were divided into six groups: controls and patients with lesions of the left and right hemispheres who were literate and illiterate. The clinical groups were based on neurological symptoms (i.e., hemiplegy and hemianopsy) because computed tomography was not yet available. The study found more difficulty determining aphasia in illiterate patients with lesions of the right hemisphere. The researchers concluded that education influences cerebral dominance (Lecours et al., 1988). Six months later, a study with aphasic patients showed poorer spontaneous recovery by literate patients with lesions of the left hemisphere than illiterate patients with lesions on the same side (Parente \& Lecours, 1998). Highlighting the contribution of this research and Prof. Lecours to Brazilian studies of cultural factors is important. Prof. Lecours went to Brazil and other South America countries several times and co-supervised master's and doctoral students who studied this subject.

The aforementioned studies with illiterate patients received severe criticism, mainly by our Portuguese colleague Prof. Alexandre Castro Caldas who had already collaborated with Prof. Damásio on similar research performed in Portugal but obtained opposite results (i.e., no differences between literate and illiterate patients; Damasio, Castro-Caldas, Grosso, \& Ferro, 1978). Methodological differences may explain these discrepancies because the Portuguese study did not include control groups, and the aphasia evaluation tools were very complex for illiterate subjects.

Curiously, 10 years later, Castro-Caldas, Petersson, Reis, Stone-Elander, and Ingvar (1998) compared elderly literate and illiterate Portuguese women and found in the illiterate subjects a greater activation of the inferior parietal region using positron emission tomography in response to the repetition of non-words. These results supported the hypothesis about the influence of education on the cerebral organization of language. At the time that this research on aphasia was conducted in illiterate subjects and with the influence of Prof. Lecours, neuropsychology groups in South America convened a meeting to create neuropsychology societies. In 1989 at the Congress of Neurology, the Sociedade Latinoamericana de Neuropsicologia (SLAN) was created in Buenos Aires, and the Sociedade Brasileira de Neuropsicologia (SBNp) was created in São Paulo. 
The biannual meetings of these societies showed that cultural factors associated with neurological evaluation and treatment was always an important topic.

\section{Studies on Language in the Right Hemisphere}

Lesions of the left hemisphere produce significant language disorders less frequently than lesions of the left hemisphere, but Joanette, Goulet, and Hannequin (1990) pointed out that lesions of the right hemisphere led to milder linguistic difficulties including difficulties comprehending and producing prosody, comprehending metaphoric language and proverbs, and comprehending complex linguistic stimuli such as speech. In Brazil, the work of Rochele Paz Fonseca confirmed these findings. Together with students from the Neuropsicologia Clínica e Experimental at PUCRS and national and international partners, the author adapted, validated, and standardized two versions of the Montreal Communication Evaluation Battery, including original expanded and short versions. Such tools examine communicative functions that can be impaired in severe neurological or psychiatric cases, mainly those related to the functions of the right hemisphere. The cognitive-communicative components examined by these tools are not examined by traditional tools that evaluate aphasias (Fonseca, Parente, Côtè, \& Joanette, 2007; Fonseca et al., 2008; Casarin, Wong, Parente, Salles, \& Fonseca, 2012). Studies conducted to date investigated communication in neurological populations and healthy individuals. In samples of healthy individuals, the effects of age and education on communicative skills have been investigated (Fonseca, Ferreira, Liedtke, Muller, Sarmento, \& Parente, 2006). More specifically, the effect of education was more frequent and robust than the effect of age, with some interactions suggesting a minor role for education with increasing age. This complex interaction corroborated the findings from international studies such as the study by Ardila, Ostrosky-Solís, Rosselli, and Gomez (2000) in Latin America. Another study conducted with patients with vascular lesions of the right hemisphere observed communication difficulties in tasks of conversational speech, free verbal fluency, phonemics and semantics, and the comprehension, repetition, and production of emotional prosody, corroborating international findings on this subject (Fonseca, Fachel, Chaves, Liedtke, \& Parente, 2007).

In a transcultural study on the role of the right hemisphere in communication, with a focus on the role of cultural variables in communication performance in patients with vascular lesions of the right hemisphere, Ferré, Fonseca, Ska, and Joanette (2012) investigated the profiles of Canadian, Brazilian, and Argentinean patients and found little effect of nationality, suggesting the relative universality of the taxonomy of communicative sequelae after lesions of the right hemisphere or aphasias of the right hemisphere.
In more specific cognitive neuropsychology studies, the relationship between communication and executive function began to be investigated in patients with traumatic brain injury and stroke (Zimmermann, Gindri, Oliveira, \& Fonseca, 2010). The findings corroborated the potential communicative alterations associated with executive function and refuted, by means of double dissociations, an interdependent relationship.

The long-standing partnership between Canadian and Brazilian research centers, first established in the 1990s by Maria Alice de Mattos Pimenta Parente and continued by Rochele Paz Fonseca, led to important scientific and technical advances in the international academic and clinical communities. Evaluation of the communicative functions of the right hemisphere was expanded to investigate other cognitive functions such as visual attention and rehabilitation of communication related mainly to pragmatic and executive functions.

In addition to this important contribution to oral language, the history of Brazilian neuropsychology is also marked by studies of written language. In this context, investigations on dyslexia and sociocultural factors in human cognition are noteworthy.

\section{Cognitive Neuropsychology and Social Factors}

Beginning in the 1990s, cognitive neuropsychology has required transdisciplinarity. This is evident from the American cognitivist movement in which scientists from different areas such as psychology, neuroanatomy, neurophysiology, and mathematics created the so-called cognitivist revolution at the Massachusetts Institute of Technology. In neuropsychology, cognitive models emerged from the work of John C. Marshall and Freda Newcombe in England (Coltheart, Patterson, \& Marshall, 1980; Marshall \& Newcombe, 1973) on deep and peripheral dyslexia. Those studies introduced the cognitive focus in neuropsychology and, thus, initial focus of cognitive neuropsychology was on reading and writing disorders. Cognitive neuropsychology was not preoccupied with descriptions of syndromes but rather the processes that generate the symptoms. Theoretical models called functional architectures or associationist networks were used to guide evaluation and rehabilitation (Lecours, Parente, \& Correa, 1991; Parente, 1990).

In the 1990s, postgraduate programs in neurosciences within this movement were created that provided more comprehensive knowledge and the formation of research in the area. The pioneer in this movement was the Programa de Pós-graduação em Neurociências e Comportamento da USP created in 1991. With the support of CAPES and CNPq, this fostered neuropsychology to officially become an interdisciplinary approach for a transdisciplinary field in which one professional has knowledge of different scientific fields, and specific methodologies and techniques can be developed.

Neuropsychology developed models for reading and writing processes that favored the study of cultural 
factors. This is because the writing system strongly depends on cultural factors and is not genetically determined. To determine whether the peculiarities of different writing systems alter the various types of dyslexia and dysgraphia, new international research was elaborated by Prof. Lecours at the University of Montreal together with Prof. Caramazza in Baltimore, Maryland. Their hypothesis was that the type of writing favors a particular type of dyslexia. Very regular language systems such as Spanish should predominantly present phonologic dyslexia (i.e., problems decoding graphemes/phonemes). Language systems without phonologic representations such as Chinese and Kanji (i.e., Japanese) should favor deep dyslexia, with failures in global and morphologic reading. Researchers from different countries collaborated and different writing systems were studied. Brazilian studies found dissociations between dyslexia and compared the Brazilian Portuguese alphabet system with Japanese morphologics (Kanji) and syllabics (Kana). Caramelli, Parente, Hosogi, Bois, and Bois (1994) described a patient with right hemispheric damage and global aphasia who was able to identify words written in Kanji (global reading) and frequent Brazilian words. This patient was unable to identify single syllables or non-words after the examiner emission written in Kana (syllabic Japanese system) or in alphabetic Portuguese written code. On the other hand, Senaha and Parente (2012) presented an exhaustive neuropsycholinguistic study of a patient that showed impaired reading in the Kanji Japanese system and, when reading, irregularly spelled Portuguese words but no effects on reading regular words and non-words in any writing system.

Neuropsychological studies showed that cultural factors, in addition to being relevant for linguistic functions, affect other cognitive functions (Rosseli \& Ardila, 2003). This phenomenon was demonstrated in Brazil when examining complex functions that involve verbal reasoning such as frontal lobe functions (Caramelli, Carthery-Goulart, Porto, Charchat-Fichman, \& Nitrini, 2007; Kristensen, Parente, \& Kazniak, 2006), simple screening tasks such as the Mini-Exame do Estado Mental (Bertolucci et al., 1994; Brucki, Nitrini, Caramelli, Bertolucci, \& Okamoto, 2003), the battery of the Consortium to Establish a Registry for Alzheimer's Disease (Nitrini et al., 2004; Takada et al., 2006), and batteries specifically developed for the evaluation of individuals with low education such as the Brief Cognitive Battery-Edu (Nitrini et al., 2007, 2008)

The influence of education on performance in the Iowa Gambling Task was noted by Bechara, Damasio, Damasio, \& Anderson (1994), a result not expected because this function should not a priori involve school learning (Bakos, Denburg, Fonseca, \& Parente, 2010). In contrast, some interactions with education have been found. In groups of subjects with low education, performance variability on cognitive tests was much higher compared with subjects with higher education (Bertolucci Brucki, Campacci, \& Juliano, 1994). One probable explanation is that reading and writing habits in the course of the adult life influence cognitive tests. A history of reading habits can correlate with language performance and other cognitive functions (Pawlowski, Remor, Parente, Salles, Fonseca, \& Bandeira, 2012). The higher variability in performance in individuals with low education may indicate that education homogenizes mental organization, but other factors like reading and writing habits may also interfere with performance in subjects with low education.

In this context, the problem of functional illiteracy has been the focus of research. The level of functional literacy should be formally evaluated in individuals with low education because of heterogeneity in the patterns of education and influence of other factors such as the cultural context, the history of work demands, and reading and writing habits (Carthery-Goulart et al., 2009a). These studies indicate the need to improve ways of conveying information to this population (CartheryGoulart et al., 2009a) and adjusting cutoff scores to improve the diagnostic accuracy of cognitive screening tests (Brucki, Mansur, Carthery-Goulart, \& Nitrini, 2011; Carthery-Goulart et al., 2009a).

Increasing the complexity of neuropsychological studies of social factors, education can also correlate with age. Moraes (2010) analyzed verbal fluency performance using tasks from the database of Fonseca et al. (2006) with curves based on analyses of probability and found that adults with moderate education (i.e., between 4 and 8 years of education) displayed a steady decline with age. However, in subjects with low education (i.e., $<4$ years) with reduced capacities, almost no decline was observed. At older ages, individuals with moderate education did not differ from subjects with low education.

In addition to education, Pawlowski et al. (2012) demonstrated that the frequency of reading and writing habits associated with years of education influenced neuropsychological performance in tasks of attention, memory, arithmetic skills, language, praxis, problemsolving, and verbal fluency. The authors also emphasized the importance of these habits for individuals with low education.

As a third sociocultural factor, Casarin et al. (2012) studied adolescents who received education in private or public schools using eight subtests of the Instrumento de Avaliação Neuropsicológica Breve (NEUPSILIN; Fonseca, Salles, \& Parente, 2009) while covarying socioeconomic level. Functions differentially affected by this factor were sustained attention, working memory, visual and semantic memory, constructive praxis, and written language.

Other studies of Brazilian samples were published that reported the effects of age and education on cognitive performance in healthy individuals such as Brucki et al. (2011) who used the Mini Exame do Estado Mental, Ribeiro, Freitas, Radanovic, \& Mansur (2010) who studied visual processing in the elderly, Naito, Uessugue, Cabral, Mansur, Radanovic, \& Mansur (2008) who used 
a lexical auditory decision task, Radanovic, Mansur, \& Scaff (2004) who used the Boston Diagnostic Aphasia Examination, and Silva, Cardoso, \& Fonseca (2012) who used the Teste de Cancelamento dos Sinos. Overall, an effect of education was identified in almost all of the tasks, especially the more complex linguistic stimulus tasks but also on visual tasks considered simple for healthy individuals in which the effect was more qualitative in the selection of successful strategies for visual canceling.

These findings are consistent with the unexpected results of international studies in clinical populations. For example, Beausoleil, Fortin, Le Blanc, \& Joanette (2003) used a sample of patients with unilateral brain damage and evaluated their performance on a verbal fluency task. The clusters obtained correlated with the level of education but not with the lateralization of the brain injury.

\section{Conclusion}

In this historical perspective, we showed that Brazilian neuropsychology followed the general path of international neuropsychology, confirming its interdisciplinary nature, search for different neural correlates, and understanding of relationships with multiple cognitive functions. The relationship between human cognition, especially the linguistic - like language structures and mechanism - and cognitive components - like attention, working memory, visual and semantic memory, constructive praxis, and written language - permeated by language, and individual sociocultural factors have marked Brazilian studies over the past three decades.

We did not discuss the following two points in detail: (1) the important insertion of neuropsychology in neurosciences, which allows comparative studies with different techniques such as animal studies and computational models and (2) the use of brain imaging techniques including functional imaging that currently allow a better understanding of the organic substrates of cognitive function. We instead focused on the fact that the sociocultural diversity of our population allows studies to search for interactions among some traditionally polemic aspects in science: predetermined biological factors such as the cerebral dominance of the left hemisphere and acquired factors. However, a subject's level of education is quite complex and can change according to the teaching system and its quality. Increasing this complexity, interactions with age and reading habits have also been found, indicating that further studies are still needed. We highlighted the need to develop short tools, both ecological and functional, for different cognitive components, especially executive function, which is still poorly understood (VerdejoGarcía \& Bechara, 2010). Research also seeks to consolidate the knowledge of neural correlates in cognition by advancing neuroimaging techniques. Both research paths will generate important results to develop more effective methods for neuropsychological rehabilitation.

\section{References}

Alajouanine, T., Ombredane, A., \& Durand, M. (1939). Le syndrome de désintégration phonétique dans l'aphasie. Paris: Masson et Cie. Amaral, V. L. A. R. (1980). Restabelecimento do repertorio verbal funcional: Estudo longitudinal de um adulto com afasia [unpublished Master's thesis]. São Paulo: Universidade São Paulo.

Ardila, A., Ostrosky-Solis, F., Rosselli, M., \& Gomez, C. (2000). Age-related cognitive decline during normal aging: The complex effect of education. Archives of Clinical Neuropsychology, 15(6), 495-513.

Austregésilo, A. (1940). Aphasie et lobe parietal gauche. Presse Médicale, 12, 126-132.

Bakos, D. S., Denburg, N., Fonseca, R. P., \& Parente, M. A. M. P. (2010). A cultural study on decision making: Performance differences on the Iowa Gambling Task between selected groups of Brazilians and Americans. Psychology \& Neuroscience, 3(1), 101-107.

Beausoleil, N., Fortin, R., Le Blanc, B., \& Joanette, Y. (2003). Unconstrained oral naming performance in right- and lefthemisphere-damaged individuals: When education overrides the lesion. Aphasiology, 17(2), 143-158.

Bechara, A., Damasio, A. R., Damasio, H., \& Anderson, S. W. (1994) Insensitivity to future consequences following damage to human prefrontal cortex. Cognition, 50(1-3), 7-15.

Bertolucci, P. H. F., Brucki, S. M. D., Campacci, S. R., \& Juliano, Y. (1994). O Mini-Exame do Estado Mental em uma população geral: Impacto da escolaridade. Arquivos de Neuropsiquiatria, 52, 1-7.

Broca, P. (1863). Localisations des fonctions cérébrales. Bulletin de la Société d'Anthropologie, 4, 200-208.

Broca, P. (1866). Sur la faculté générale du langage, dans ses rapports avec la faculté du langage articulé. Bulletin de la Société d'Anthropologie Deuxième, 1, 377-382.

Brucki, S. M., Nitrini, R., Caramelli, P., Bertolucci, P. H., Okamoto, I. H. (2003). Sugestões parao uso do mini-exame do estado mental no Brasil. Arquivos de Neuropsiquiatria, 61(3-B), 777-781.

Brucki, S. M. D., Mansur, L. L., Carthery-Goulart, M. T., \& Nitrini, R. (2011). Formal education, health literacy and Mini-Mental State Examination. Dementia \& Neuropsychologia, 5(1), 26-30.

Caldas, V. S. (1891). Da aphasia e suas formas [unpublished doctoral thesis]. Rio de Janeiro: Universidade Federal do Rio de Janeiro.

Campos, J. A. S. (1921). Aphasia [unpublished doctoral thesis]. Rio de Janeiro: Universidade Federal do Rio de Janeiro.

Caramelli, P., Carthery-Goulart, M. T., Porto, C. S., Charchat-Fichman, H., \& Nitrini, R. (2007). Category fluency as a screening test for Alzheimer disease in illiterate and literate patients. Alzheimer Disease and Associated Disorders, 21(1), 65-67.

Caramelli, P., Parente, M. A. M. P., Hosogi, M. L., Bois, M., \& Bois, M. (1994). Unexpected reading dissociation in a Brazilian "nisei" with crossed aphasia. Behavioural Neurology, 7(3-4), 165-170.

Carthery-Goulart, M. T., Anghinah, R., Areza-Fegyveres, R., Bahia, V. S., Brucki, S. M., Damin, A., ... Nitrini, R. (2009a). Performance of a Brazilian population on the test of functional health literacy in adults. Revista de Saúde Pública (USP. Impresso), 43, 631-638.

Casarin, F. S., Wong, C. E. I., Parente, M. A. M. P., Salles, J. F., \& Fonseca, R. P. (2012). Comparison of neuropsychological performance between students from public and private Brazilian schools. Spanish Journal of Psychology, 15(3), 942-951.

Castro-Caldas, A., Petersson, K. M., Reis, A., Stone-Elander, S., \& Ingvar, M. (1998). The illiterate brain: Learning to read and write during childhood influences the functional organization of the adult brain. Brain, 121(6), 1053-1063.

Coltheart, M., Patterson, K., \& Marshall, J. C. (1980). Deep dyslexia. London: Routledge \& Kegan Paul.

Critchley, M. (1957). Aphasiology and other disorders of speech. London: Edwin Arnold.

Damasio, A. R., Castro-Caldas, A., Grosso, J. T., \& Ferro, J. M. (1976). Brain specialization for language does not depend on literacy. Archives of Neurology, 33(4), 300-301.

Ferré, P., Fonseca, R. P., Ska, B., \& Joanette, Y. (2012). Communicative clusters after a right-hemisphere stroke: Are there universal clinical profiles? Folia Phoniatrica et Logopaedica, 64, 199-207.

Fonseca, R. P., Fachel, J. M. G., Chaves, M. L. F., Liedtke, F. V., \& Parente, M. A. M. P. (2007). Right hemisphere damage: Communication processing in adults evaluated by the Brazilian Protocole MEC Bateria MAC. Dementia \& Neuropsychologia, 1, 266-275.

Fonseca, R. P., Ferreira, G. D., Liedtke, F. V., Muller, J., Sarmento, T., \& Parente, M. A. M. P. (2006). Alterações cognitivas, 
comunicativas e emocionais após lesão hemisférica direita: Em busca de uma caracterização da Síndrome do Hemisfério Direito. Psicologia USP, 17, 241-262.

Fonseca, R. P., Joanette, Y., Cote, H., Ska, B., Giroux, F., Fachel, J. M. G., ... Parente, M. A. M. P. (2008). Brazilian version of the Protocole Montréal d'evaluation de la Communication (Protocole MEC): Normative and reliability data. Spanish Journal of Psychology, 11(2), 678-688.

Fonseca, R. P., Parente, M. A. M. P., Côtè, H., \& Joanette, Y. (2007). Processo de adaptação da Bateria Montreal de Avaliação da Comunicação - Bateria MAC - ao Português Brasileiro. Psicologia: Reflexão e Crítica, 20, 257-266.

Fonseca, R. P., Salles, J. F., \& Parente, M. A. M. P. (2008). Development and content validity of the Brazilian Brief Neuropsychological Assessment Battery Neupsilin. Psychology \& Neuroscience, 1 55-62.

Fonseca, R. P., Scherer, L. C., Oliveira, C. R., \& Parente, M. A. M. P. (2009). Hemispheric specialization in communicative processing: Neuroimaging data on the role of the right hemisphere. Psychology \& Neuroscience, 2, 25-33.

Goulart, O. (1891). Estudo Psycho-clínico da Afasia. Tese apresentada Na Faculdade de Medicina do Rio de Janeiro.

Jacubovicz, R. C., \& Cupello, R. (2005). Introdução à afasia: Diagnóstico e terapia. Rio de Janeiro: Revinter.

Joanette, Y., Goulet, P., \& Hannequin, D. (1990). Right hemisphere and verbal communication. New York: Springer-Verlag.

Kimura, D. (1961). Cerebral dominance and the perception of verbal stimuli. Canadian Journal of Psychology, 15(3), 166-171.

Kinsbourne, M. (1973). The control of attention by interaction between the cerebral hemisphere. In: S. Kornblum (Ed.), Attention and performance IV (pp. 239-258). New York: Academic Press.

Kristensen, C. H., Parente, M. A. M. P., \& Kazniak, A. (2006). Transtorno de estresse pós-traumático e funções cognitivas. Revista Psico-USF, 11, 17-34.

Lebrun, Y., \& Parente, M. A. M. P. (1983). Tratado das afasias. São Paulo: Panamed.

Lecours, A. R., Parente, M. A. M. P., Correa, L. M. (1991). A noção do léxico mental: Memórias e processos translexicais. Lugar em Fonoaudiologia, 4, 4-18.

Lecours, A. R., Mehler, J., Parente, M. A. M. P., Beltrami, M. C., Canossa de Tolipan, L., Cary, L., ... Teixeira, M. (1988). Illiteracy in brain damage: 3. A contribution to the study of speech and language disorders in illiterates with unilateral brain damage (initial testing). Neuropsychologia, 26(4), 575-589.

Lecours, A. R., Parente, M. A. M. P., Correa, L. M. (1990). A Noção do Léxico Mental: Memórias e Processos Perilexicais. Lugar em Fonoaudiologia, 3:5-23,

Lefèvre, A. B. (1950). Contribuição para o estudo da psicopatologia da afasia em crianças. Arquivos de Neuropsiquiatria, 8, 345.

Lefèvre A. B. (1974) Classificação dos distúrbios clínicos da comunicação através da fala, escrita e leitura. Revista Brasileira de Deficiência Mental, 4, 40-45.

Lefèvre, A. B. (1975). Language development in malnourished children. In: E. H. Lennenberg, \& Lenneberg, E. (Ed.), Foundations of language development: A multidisciplinary approach (pp. 279295). New York: Academic Press.

Lefèvre, A. B., \& Lefèvre, B. H. (1975). Disfunção cerebral mínima: Estudo multidisciplinar. São Paulo: Sarvier

Lennenberg, E. H., \& Lenneberg, E. (1975). Foundations of language development: A multidisciplinary approach. New York: Academic Press.

Levy-Agresti, J., \& Sperry, R. W. (1968). Differential perceptual capacities in major and minor hemispheres. Proceedings of the National Academy of Sciences of the United States of America, 61, 1151

Luria, A. R. (1966). Higher cortical functions in man. London: Tavistock Publications.

Marks, M., Taylor, M., \& Rusk, H. A. (1957). Rehabilitation of the aphasic patient: A survey of three years' experience in a rehabilitation setting. Neurology, 7(12), 837-843.

Marshall, J. C., \& Newcombe, F. (1973). Patterns of paralexia: A psycholinguistic approach. Journal of Psycholinguistic Research, 2(3), 175-199.

Moraes, A. (2010). Envelhecimento neurocognitivo e tarefas de fluência verbal: Efeito da idade e de variáveis socioculturais nos processamentos executivos e léxico-semânticos. [unpublished Master's dissertation]. Porto Alegre: Universidade Federal do Rio Grande do Sul.
Naito, F., Uessugue, V. L., Cabral, R. A., Mansur, L., Radanovic, M., \& Mansur, L. L. (2008). Effect of schooling in auditory lexical decision. Dementia \& Neuropsychologia, 2(2), 125-130.

Nitrini, R., Brucki, S. M. D., Smid, J., Carthery-Goulart, M. T., Anghinah, R., Areza-Fegyveres, R., ... Mansur, L. L. (2008). Influence of age, gender and educational level on performance in the Brief Cognitive Battery-Edu. Dementia \& Neuropsychologia, 2(2), 114-118.

Nitrini, R., Caramelli, P., Herrera, E., Jr., Porto, C. S., CharchatFichman, H., Carthery, M. T., ... Lima, E. P. (2004). Performance of illiterate and literate nondemented elderly subjects in two tests of long-term memory. Journal of the International Neuropsychological Society, 10, 634-638.

Nitrini, R., Caramelli, P., Porto, C. S., Charchat-Fichman, H., Formigoni, A. P., Carthery-Goulart, M. T., ... Prandini, J. C. (2007). Brief cognitive battery in the diagnosis of mild Alzheimer's disease in subjects with medium and high levels of education. Dementia \& Neuropsychologia, 1, 32-36.

Ombredane, A. (1943-1944a). Etudes de psychologie médicale: I. Perception et langage. Rio de Janeiro: Atlantica Editora.

Ombredane, A. (1943-1944b). Etudes de psychologie médicale: II. Geste et action. Rio de Janeiro: Atlantica Editora.

Ombredane, A. (1943-1944c). Etudes de psychologie médicale: III. Troubles du caractère et délires. Rio de Janeiro: Atlantica Editora.

Parente, M. A. M. P. (1984). Habilidades construtivas em analfabetos [unpublished Master's thesis]. São Paulo: Pontifícia Universidade Católica de São Paulo.

Parente, M. A. M. P. (1990). Assimetrias hemisféricas cerebrais na percepção de fotografias [unpublished thesis]. São Paulo: Instituto de Psicologia da Universidade de São Paulo.

Parente, M. A. M. P., \& Lecours, A. R. (1998). Participação do hemisfério direito na recuperação das afasias de analfabetos. Neuropsicologia Latina, 4(2), 73-78.

Parente, M. A. M. P., \& Pimenta, M. A. (1977). Estudo das altas funções corticais em afásicos na localização de tumores. Seara Médica Neurocirúrgica, 4, 57-64.

Parente, M. A. M. P., \& Tiedemann, K. B. (1990). Hemispheric asymmetries in the recognition of animal photographs in different views. Brazilian Journal of Medical and Biological Research, 23(11), 1201-1204.

Parente, M. A. P. P. (1974). Alterações na linguagem na patologia do lobo temporal avaliadas pela técnica de Luria. Seara Medica Neurocirúrgica, 3(4), 305-314.

Parente, M. A. P. P. (1981). Como eu vejo afasia do ponto de vista fonoaudiologico. Seara Médica Neurocirurgia, 10, 355-365.

Pawlowski, J., Remor, E., Parente, M. A. P. P., Salles, J. F., Fonseca, R. P., \& Bandeira, D. (2012). The influence of reading and writing habits associated with education on the neuropsychological performance of Brazilian adults. Reading \& Writing, 15(9), 2275-2289.

Pinto, A. C. (1910). Capacidade civil dos aphasicos [unpublished doctoral thesis]. Porto Alegre: Universidade Federal do Rio Grande do Sul.

Radanovic, M., Mansur, L. L., \& Scaff, M. (2004). Normative data for the Brazilian population in the Boston Diagnostic Aphasia Examination: Influence of schooling. Brazilian Journal of Medical and Biological Research, 37(11), 1731-1738.

Ribancourt, B. D. (1988). Rééducation sémiologique de l'aphasie. Paris: Masson et Cie.

Ribeiro, A. R., Freitas, M. I. Á., Radanovic, M., \& Mansur, L. L. (2010). The generation of visual inferences in normal elderly: Influence of schooling and visual complexity. Dementia \& Neuropsychologia, 4(3), 194-201.

Rosselli, M., \& Ardila, A. (2003). The impact of culture and education on non-verbal neuropsychological measurements: A critical review. Brain and Cognition, 52(3), 326-333.

Sampaio, J. S. S. B. (1912). Um caso de aphasia palustre [unpublished doctoral thesis]. Canela Salvador: Universidade Federal da Bahia.

Schuell, H., Jenkins, J. J., \& Jiménes-Pabon, E. (1964). Aphasia in adults: Diagnosis, prognosis, and therapy. New York: Hoeber.

Senaha, M. L. H., \& Parente, M. A. M. P. (2012). Acquired dyslexia in three writing systems: Study of a Portuguese-Japanese bilingual aphasic patient. Behavioural Neurology, 25(3), 255-272.

Silva, R. F. C., Cardoso, C., \& Fonseca, R. P. (2012). Diferenças quanto à escolaridade em adultos no desempenho no Teste de Cancelamento dos Sinos. Estudos de Psicologia (Natal. Online), $17,215-222$

Souza, B. M. (1908). A evolução da doutrina da afasia [unpublished doctoral thesis]. Rio de Janeiro: Universidade Federal do Rio de Janeiro. 
Sperry, R. W. (1961). Cerebral organization and behavior: The split brain behaves in many respects like two separate brains, providing new research possibilities. Science, 133(3466), 1749-1757.

Springer, J. A., Binder, J. R., Hammeke, T. A., Swanson, S. J., Frost, J. A., Bellgowan, P. S., ... Mueller, W. M. (1999). Language dominance in neurologically normal and epilepsy subjects: A functional MRI study. Brain, 122(11), 2033-2046.

Takada, L. T., Caramelli, P., Charchat-Fichman, H., Porto, C. S., Bahia, V. S., Anghinah, R., ... Herrera, E., Jr. (2006). Comparison between two tests of delayed recall for the diagnosis of dementia. Arquivos de Neuropsiquiatria, 64(1), 35-40.
Taylor, M. (1958). Communication disorders. In: H. A. Rusk (Ed.), Rehabilitation medicine: A textbook on physical medicine and rehabilitation (pp. 248-250). St. Louis: C.V. Mosby.

Verdejo-García, A., \& Bechara, A. (2010). Neuropsicología de las funciones ejecutivas. Psicothema, 22(2), 227-235.

Woods, B. T., \& Teuber, H. L. (1978). Changing patterns of childhood aphasia. Archives of Neurology, 3(3), 273-280.

Zimmermann, N., Gindri, G., Oliveira, C. R., \& Fonseca, R. P. (2011). Pragmatic and executive functions in traumatic brain injury and right brain damage. Dementia \& Neuropsychologia, $5,337-345$ 
